\title{
Clinical mesenchymal stem cell therapy in ischemic cardiomyopathy
}

Amine Mazine, MD, MSc, Dinela Rushani, MD, MSc, and Terrence M. Yau, MD, MSc

Feature Editor's Introduction-Nearly 20 years ago, experimental reports of myocardial repair and regeneration with bone marrow-derived stem cells began to appear in the literature. The hypothesis that adult hearts had capacity for regeneration was contrary to prior science and generated intense interest in both research and clinical communities. This led to early clinical trials evaluating the safety and efficacy of various types of stem cells for the treatment of ischemic cardiomyopathy. Some researchers in the field believed that translation of experimental work into the clinical realm occurred rapidly and impulsively. As these trials progressed, 1 by 1 the experimental reports of myocardial regeneration were refuted, and a new hypothesis-that stem cell treatment improves cardiac function through a paracrine effect-was born. The result is a sobering tale of how early acceptance of shaky experimental data can impede scientific progress for years. Dr Yau and colleagues critically evaluate the clinical trial data on mesenchymal stem cell therapy in humans with ischemic cardiomyopathy. They identify several reasons why the results of trials have been inconsistent and propose important ways in which we can better evaluate the efficacy of this therapy in the future.

\section{Leora B. Balsam, MD}

Chronic heart failure affects an estimated 26 million people worldwide and is the leading cause of hospitalization in North America and Europe. ${ }^{1}$ Ischemic heart disease is the most common cause of heart failure. ${ }^{2}$ Although advances in early reperfusion therapy have significantly reduced the early mortality associated with myocardial infarction, many patients develop heart failure secondary to the

\footnotetext{
From the Division of Cardiovascular Surgery, Peter Munk Cardiac Center, Toronto General Hospital, University Health Network, University of Toronto, Toronto, Ontario, Canada.

Received for publication Nov 16, 2020; accepted for publication June 8, 2021; available ahead of print Aug 26, 2021.

Address for reprints: Terrence M. Yau, MD, MSc, Division of Cardiovascular Surgery, Peter Munk Cardiac Center, Toronto General Hospital, University Health Network, University of Toronto, 200 Elizabeth St, 4N-470, Toronto, Ontario M5G 2C4, Canada (E-mail: terry.yau@uhn.on.ca).

JTCVS Open 2021;8:135-41

2666-2736

Copyright $($ C) 2021 The Author(s). Published by Elsevier Inc. on behalf of The American Association for Thoracic Surgery. This is an open access article under the CC BY-NC-ND license (http://creativecommons.org/licenses/by-nc-nd/4.0/). https://doi.org/10.1016/j.xjon.2021.06.030
}

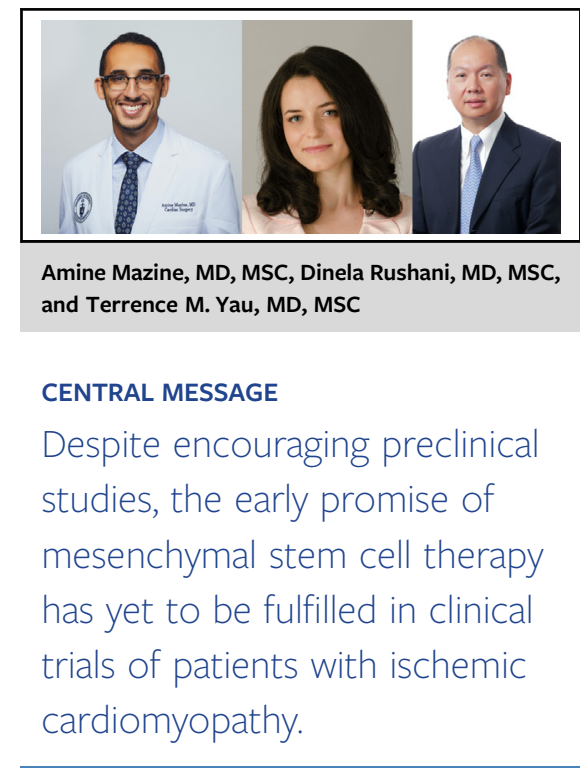

See Commentaries on pages 142 and 144

ventricular remodeling after an acute coronary event. Advances in guideline-directed medical therapy, including angiotensin-converting enzyme inhibitors, angiotensin II receptor blockers, $\beta$-blockers, mineralocorticoid receptor blockers, and angiotensin receptor neprilysin inhibitors, have substantially reduced the mortality associated with chronic heart failure. ${ }^{3}$ Nonetheless, this condition carries considerable morbidity and mortality because current medical therapies mitigate adverse ventricular remodeling but do not repair the underlying damage caused by the loss of cardiomyocytes. Thus, there remains an unmet need for novel therapies that durably restore ventricular function in patients with chronic ischemic cardiomyopathy (ICM).

In recent years, stem cell therapy for cardiac regeneration has emerged as a promising therapeutic avenue. Among various candidate cell types, mesenchymal stem cells (MSCs) have garnered particular interest due to their ease of procurement, extensive proliferation in vitro, and broad immunomodulatory and anti-inflammatory properties. These stromal cells are found in a variety of tissues and are loosely defined as $\mathrm{CD} 105^{+} \mathrm{CD} 73^{+} \mathrm{CD} 90^{+} /$ $\mathrm{CD} 45^{-} \mathrm{CD} 34^{-} \mathrm{CD} 14^{-} \mathrm{CD} 19^{-}$cells that are plastic-adherent when cultured in vitro and can differentiate into osteoblasts, adipocytes, and chondroblasts. ${ }^{4}$ Over the past 2 decades, MSCs have been extensively evaluated to treat various 
cardiac conditions in both preclinical and clinical studies. Herein, we review the clinical evidence surrounding MSC use in the treatment of ICM.

\section{PRECLINICAL STUDIES}

Although a detailed analysis of the preclinical studies of MSC therapy for ICM is beyond the scope of this review, it is worth mentioning that these cells have been extensively studied in small and large animal models, using multiple cell sources (eg, allogeneic vs autologous and bone marrow- vs adipose tissue-derived) and routes of administration (eg, direct transepicardial injection, transendocardial, intracoronary, and intravenous). ${ }^{5}$ Collectively, these preclinical studies have demonstrated that MSC therapy is effective at reducing scar size and improving left ventricular (LV) ejection fraction (LVEF) after myocardial infarction. A meta-analysis of 52 preclinical large animal studies showed that cell therapy is associated with a moderate $7.5 \%$ improvement in LVEF in animals with ICM. ${ }^{6}$ Furthermore, this study demonstrated that MSCs from any source (ie, bone marrow, adipose tissue, or umbilical cord) were more effective at improving LVEF compared with bone marrow-derived mononuclear cells (BMCs).

\section{MECHANISM OF ACTION IN HUMANS}

Early theories that MSCs engraft in the myocardium and replace damaged cardiomyocytes have been refuted. ${ }^{7,8} \mathrm{~A}$ hypothesis that the heart itself contains a population of c-Kit ${ }^{+}$stem cells that are stimulated by MSCs to differentiate into cardiomyocytes has also been disproven. ${ }^{9}$ The alternative- and now widely accepted — explanation for the beneficial effects of MSCs on cardiac function is the paracrine hypothesis, which stipulates that MSCs secrete poorly characterized paracrine factors with antifibrotic and proangiogenic effects on injured heart tissue. ${ }^{10,11}$ To test this hypothesis, the Prospective Randomized Study of Mesenchymal Stem Cell Therapy in Patients Undergoing Cardiac Surgery trial delivered autologous MSCs to akinetic and hypokinetic myocardium unsuitable for revascularization in 6 patients. ${ }^{12}$ A reduction in scar size and modest improvements in tissue perfusion were observed in the MSC-treated patients, as assessed by magnetic resonance imaging (MRI). However, given the small sample size and lack of a placebo group, these findings remained hypothesis-generating.

\section{CLINICAL TRIALS}

On the basis of these preclinical and mechanistic studies, several randomized clinical trials of MSC therapy for ICM have been conducted. These trials consist of small Phase 1 and 2 studies, with no successful Phase 3 trials of MSC therapy for ICM reported to date. Below, we summarize the findings from some landmark trials before offering a broad perspective on the totality of the available evidence (Table 1).

\section{SUMMARY OF LANDMARK STUDIES POSEIDON Trial (2012)}

The POSEIDON (Percutaneous Stem Cell Injection Delivery Effects on Neomyogenesis) trial ${ }^{13}$ was a Phase 1 and 2, single-center, randomized, nonplacebo controlled comparison of transendocardial allogenic versus autologous MSCs in 30 patients with ICM and LV dysfunction. Three doses (20 million, 100 million, and 200 million cells) were tested per group. The primary end point was a composite of serious adverse events (SAEs): death, nonfatal myocardial infarction, stroke, hospitalization for worsening heart failure, cardiac perforation, tamponade, or sustained ventricular arrhythmia. An SAE occurred in 1 patient per group $(6.7 \%)$ within 30 days, in 5 patients $(33 \%)$ in the allogeneic group, and in 8 patients $(53 \%)$ in the autologous group $(P=.46)$ within 1 year. Regarding 1 -year secondary end points, both groups showed a reduction in infarct size and LV sphericity index compared with baseline, but no statistically significant improvement in LVEF. Autologous, but not allogeneic MSC therapy resulted in modest improvements in the 6-minute walk test and quality of life (QOL) score. Reductions in LV end-systolic volume (LVESV) and increases in LVEF were greater in patients who received 20 million versus 200 million MSCs, an inverse dose response speculatively due to impaired MSC survival at higher concentrations, a need for an optimal number of cells to reconstitute cell niches and/or paradoxically reduced cell retention with higher doses. ${ }^{14}$

\section{TAC-HFT Trial (2014)}

TAC-HFT (Transendocardial Autologous Cells in Ischemic Heart Failure Trial) ${ }^{15}$ was a Phase 1 and 2 randomized, blinded, placebo-controlled study of 65 patients with ICM and LVEF $<50 \%$ who received transendocardial autologous MSCs $(\mathrm{n}=19)$, BMCs $(\mathrm{n}=19)$, or placebo $(\mathrm{n}=21)$. No patient experienced an SAE (a composite as per POSEIDON) at 30 days. The 1-year incidence of SAE was $32 \%$ for the MSC and BMC groups, and $38 \%$ for placebo. At 1 year, QOL scores improved with both MSCs and BMCs compared with placebo. However, 6-minute walk test results and infarct size improved only with MSCs. LV volumes and LVEF were unchanged in all groups.

\section{PRECISE Trial (2014)}

The PRECISE (Randomized Clinical Trial of Adiposederived Stem Cells in Treatment of Non Revascularizable Ischemic Myocardium) trial ${ }^{16}$ was the first randomized, placebo-controlled, double-blind trial to examine the safety and feasibility of transendocardially administered adiposederived MSCs in patients with ICM. In 21 MSC-treated and 6 control patients, no complications were observed with cell harvest or injection. At 18 months, the incidence of major adverse cardiac or cerebral events was similar between 


\begin{tabular}{|c|c|c|c|c|}
\hline Study & Study design & Population & Intervention vs comparison & Outcomes \\
\hline POSEIDON (2012) & $\begin{array}{l}\text { Randomized, } \\
\text { nonplacebo } \\
\text { controlled }\end{array}$ & $\begin{array}{l}30 \text { patients with ICM and left } \\
\text { ventricular dysfunction }\end{array}$ & $\begin{array}{l}3 \text { doses of transendocardial allogenic vs } \\
\text { autologous MSCs }(20,100,200 \text { million } \\
\text { cells) }\end{array}$ & $\begin{array}{l}\text { - No difference in SAEs*, infarct size, LV sphericity } \\
\text { index, LVEF in allogenic vs autologous MSC } \\
\text { - Autologous MSC: modest improvement in 6-min walk } \\
\text { test and QOL } \\
\text { - } 20 \text { million cells yielded better LVESV and LVEF vs } \\
200 \text { million cells }\end{array}$ \\
\hline TAC-HFT (2014) & $\begin{array}{l}\text { Randomized, } \\
\text { placebo } \\
\text { controlled }\end{array}$ & $\begin{array}{l}65 \text { patients with ICM and LVEF } \\
<50 \%\end{array}$ & $\begin{array}{l}\text { Transendocardial autologous MSCs or BMCs } \\
\text { vs placebo }\end{array}$ & $\begin{array}{l}\text { - No difference in SAEs, LV volume, or LVEF } \\
\text { - Improved 6-min walk test and infarct size only with } \\
\text { MSC } \\
\text { - Better QOL with MSC or BMC, but not placebo }\end{array}$ \\
\hline PRECISE (2014) & $\begin{array}{l}\text { Randomized, } \\
\text { placebo } \\
\text { controlled }\end{array}$ & 27 patients with ICM & $\begin{array}{l}\text { Transendocardial adipose derived MSCs vs } \\
\text { placebo }\end{array}$ & $\begin{array}{l}\text { - No difference in major adverse cardiac or cerebral } \\
\text { events, LVEF, LV volumes } \\
\text { - Modest improvement in LV mass and wall motion } \\
\text { score index only in MSC } \\
\text { - Decline in metabolic equivalents and maximum } \\
\text { oxygen consumption only in placebo }\end{array}$ \\
\hline MSC-HF $(2015,2020)$ & $\begin{array}{l}\text { Randomized, } \\
\text { placebo } \\
\text { controlled }\end{array}$ & $\begin{array}{l}60 \text { patients with ICM, NYHA } \\
\text { functional class II-III, LVEF } \\
<45 \%\end{array}$ & $\begin{array}{l}\text { Intramyocardial autologous bone derived } \\
\text { MSCs vs placebo }\end{array}$ & $\begin{array}{l}\text { - At } 6 \text { mo, reduced LVESV and improved LVEF, stroke } \\
\text { volume, cardiac output, myocardial mass only in MSC } \\
\text { group; but no difference in NYHA functional class, } \\
\text { 6-min walk test, or QOL } \\
\text { - At } 1 \text { y, improved LVEF, stroke volume, myocardial } \\
\text { mass, and QOL and fewer angina hospitalizations at } \\
4 \text { y only in MSC group }\end{array}$ \\
\hline RIMECARD (2017) & $\begin{array}{l}\text { Randomized, } \\
\text { placebo } \\
\text { controlled }\end{array}$ & $\begin{array}{l}21 \text { patients with ICM and reduced } \\
\text { LVEF and } 9 \text { patients without ICM }\end{array}$ & $\begin{array}{l}\text { Intravenous allogeneic umbilical cord } \\
\text { derived MSC vs placebo }\end{array}$ & $\begin{array}{l}\text { - No difference in adverse events, mortality, heart } \\
\text { failure hospitalization, maximum oxygen } \\
\text { consumption, metabolic equivalents, exercise } \\
\text { tolerance between groups } \\
\text { - Improvement in LVEF, NYHA functional class, and } \\
\text { QOL only in MSC }\end{array}$ \\
\hline LVAD MPC2 (2019) & $\begin{array}{l}\text { Randomized, } \\
\text { placebo } \\
\text { controlled }\end{array}$ & $\begin{array}{l}159 \text { patients with end-stage heart } \\
\text { failure due to ICM }(44 \%) \text { or non- } \\
\text { ICM }(56 \%) \text {, undergoing LVAD } \\
\text { implantation }\end{array}$ & $\begin{array}{l}150 \text { million mesenchymal progenitor cells vs } \\
\text { placebo }\end{array}$ & $\begin{array}{l}\text { - No safety end point events in either group } \\
\text { (myocarditis, myocardial rupture, neoplasms, } \\
\text { hypersensitivity reactions, and immune sensitization) } \\
\text { - No difference in ability to tolerate temporary wean } \\
\text { from LVAD }\end{array}$ \\
\hline
\end{tabular}


the groups (17\% in the control group and $10 \%$ in the treatment group). On echocardiography, LVEF and LV volumes were unchanged in the MSC group compared with their baseline or the placebo. On MRI, there were modest improvements in LV total mass and wall motion score index only with MSCs. Metabolic equivalents and maximum oxygen consumption were preserved over time in the MSC group, but declined significantly among control patients.

\section{MSC-HF Trial (2015)}

The MSC-HF (Autologous Mesenchymal Stromal Cell Therapy in Heart Failure Trial) trial ${ }^{17}$ was another Phase 2, single-center, randomized, double-blind, placebocontrolled trial studying the effects of intramyocardially administered autologous bone marrow-derived MSCs in patients with ICM. Sixty patients aged 30 to 80 years with severe ischemic heart failure, New York Heart Association (NYHA) functional class II or III symptoms, and LVEF $<45 \%$ were randomized 2:1 to MSC treatment or placebo. The primary end point was change in LVESV at 6 months measured by MRI or computed tomography. At 6 months, LVESV was reduced compared with baseline in the MSC group and increased in the placebo group. Compared with placebo, there were also significant improvements in LVEF, stroke volume, cardiac output, and myocardial mass in MSC-treated patients. In contrast to these imaging outcomes, no differences were observed in NYHA class, 6minute walk test, and QOL score between the groups. Rates of SAEs were not statistically different between the treatment (14 SAEs in 40 patients) and control (17 SAEs in 20 patients) groups. After a longer follow-up, MSC-treated patients showed improved LVEF, stroke volume, myocardial mass, scar tissue, and QOL score at 12 months, as well as reduced hospitalizations for angina at 4 years. ${ }^{18}$ Unlike the POSEIDON trial, a positive dose response was observed, in that patients with the highest number of injected MSCs experienced greater improvement in systolic function.

\section{RIMECARD Trial (2017)}

RIMECARD (Randomized Clinical Trial of Intravenous Infusion Umbilical Cord Mesenchymal Stem Cells on Cardiopathy ${ }^{19}$ was the first clinical trial to evaluate the safety and efficacy of intravenous infusion of allogeneic umbilical cord-derived MSCs in patients with heart failure and reduced LVEF. This Phase 1 and 2, double-blind, placebocontrolled trial was conducted in 2 centers in Chile and randomized 1:1 30 patients with ischemic ( $70 \%$ of patients) or nonischemic cardiomyopathy. No adverse events related to cell infusion were observed. Only MSC-treated patients showed significant improvement in LVEF at 3, 6, and 12 months, as well as in NYHA functional class and QOL scores. No differences were observed between groups in mortality, heart failure hospitalizations, maximum oxygen consumption, metabolic equivalents, or exercise tolerance. At 12 months, a total of 10 adverse events occurred in 15 patients in the treatment group versus 13 adverse events in 15 patients in the control group.

\section{LVAD MPC2 Trial (2019)}

The LVAD MPC2 (Safety \& Efficacy of Intramyocardial Injection of Mesenchymal Precursor Cells on Myocardial Function in LVAD Recipients Trial) trial ${ }^{20}$ enrolled 159 patients with end-stage heart failure due to ICM $(44 \%)$ or nonischemic cardiomyopathy (56\%) undergoing LVAD implantation. Patients were randomized to receive 150 million mesenchymal progenitor cells (a Stro-3+ subfraction of MSCs) or placebo. No patient experienced a primary safety end point (myocarditis, myocardial rupture, neoplasm, hypersensitivity reactions, or immune sensitization). The primary efficacy outcome-ability to tolerate a temporary wean from LVAD support-did not differ in the overall trial population between patients receiving MPCs and those receiving placebo, but additional analyses in patients with ICM, in whom MPCs mechanistically may be anticipated to have greater potential benefit, are pending.

\section{SYNTHESIS OF THE AVAILABLE EVIDENCE}

Several meta-analyses of Phase 1 and 2 clinical trials of MSC therapy in patients with ICM have suggested that in patients with chronic ICM and reduced LVEF, intramyocardial MSCs modestly improve LV function and clinical outcomes. ${ }^{21}$ However, such meta-analyses must be interpreted cautiously in light of the low quality of evidence and the limitations of the individual studies, including small samples, multiple statistical tests of secondary end points, and heterogeneity of individual trials (eg, differences in sources of MSCs and types of cells administered, methods of delivery, doses, and culture conditions).

As detailed in the previous section, MSC trials have shown inconsistent and mostly marginal influence on cardiac function, and no substantial benefit on hard clinical outcomes such as mortality or rehospitalization for heart failure. Furthermore, it has been suggested that studies with the most technical errors have reported the most positive effects of MSC therapy on $\mathrm{LVEF}^{22}$ raising the possibility that a lack of rigor may have generated a positive bias overstating the functional benefits of MSCs.

In light of the ambiguous outcomes of Phase 1 and 2 clinical trials, Phase 3 trials using current iterations of MSC protocols may require many thousands of enrolled patients to demonstrate robust clinical benefit, assuming that such a benefit exists. Thus, there remains a need to develop strategies to enhance the potency of MSCs. In the next section, we review potential strategies that are currently being explored. 


\section{IMPROVING THE EFFICACY OF MSC THERAPY Cell Priming}

One strategy for MSC therapy optimization is cellular preconditioning. This consists of the priming of MSCs before injection, either through the use of genetic modifications intended to rejuvenate the cells, or by altering their culture conditions; for example, through the use of hypoxic culture medium, cytokines, or growth factors. ${ }^{23,24}$ Although promising in preclinical studies, clinical trial results of this approach have thus far been disappointing. For example, in the MyStromalCell trial, intramyocardial autologous vascular endothelial growth factor-A-stimulated adiposederived MSCs did not improve exercise capacity in patients with chronic ischemic heart disease compared with placebo. ${ }^{25}$ Similarly, the CHART-1 (Safety and Efficacy of Autologous Cardiopoietic Cells for Treatment of Ischemic Heart Failure trial) trial was a multinational, double-blind, sham-controlled study conducted in 315 patients with symptomatic ischemic heart failure. ${ }^{26}$ Patients were randomized 1:1 to receive intramyocardial autologous bone marrow-derived MSCs or placebo. The MSCs were pretreated with a cardiopoietic cocktail containing transforming growth factor- $\beta$, bone morphogenetic protein 4, activin A, fibroblast growth factor 2, cardiotrophin, and $\alpha$-thrombin. ${ }^{27}$ At 39 weeks, the primary end point-a hierarchical composite of all-cause mortality, worsening heart failure, Minnesota Living with Heart Failure Questionnaire score, 6-minute walk distance, LVESV, and LVEF-was neutral between the MSC and placebo groups. In exploratory post-hoc analyses, MSC-treated patients had decreased LV end diastolic volume and LVESV at 1 -year, ${ }^{28}$ and fewer primary composite end point events in a subgroup of patients with increased LV end diastolic volume at baseline. ${ }^{26}$ However, these per-protocol analyses were not prespecified and should therefore be interpreted cautiously.

\section{Cell Combination}

Another promising approach is mixing MSCs with other cell types (eg, endothelial cells and immune cells) to potentiate their effects. A compelling clinical application of this approach is the ixCELL-DCM (Ixmyelocel-T for Patients With Ischaemic Heart Failure trial) trial, a multicenter, randomized, double-blind, placebo-controlled Phase 2 trial in which patients with symptomatic ischemic heart failure were randomized 1:1 to receive ixmyelocel-T-a combination of autologous bone marrow-derived MSCs and macrophages-or placebo. ${ }^{29}$ The study enrolled 126 patients across 31 sites in North America. The primary end point was a composite of all-cause mortality, cardiovascular admission to hospital, and unplanned clinic visits to treat acute decompensated heart failure. In a modified intention-to-treat analysis, there was a $37 \%$ reduction in the primary end point in the treatment group, making ixCELL-DCM among the very few clinical trials demonstrating a strong clinical benefit of MSC therapy in patients with ICM. Because the trial did not include a MSC alone or macrophage alone group, the relative importance of individual cell types versus their synergistic effect cannot be ascertained.

\section{Seeding on Tissue Engineered Scaffolds}

Most clinical trials of MSC therapy for ICM have relied on direct intramyocardial injection or intravascular infusion for cell delivery. These approaches yield low rates of cell engraftment and retention, which may limit treatment effectiveness. To overcome this problem, many groups have advocated enhancing cell engraftment by providing structural support to the cells using tissue engineering approaches. Some preclinical studies have shown that the effects of MSC therapy can be enhanced by seeding the cells on tissue engineered patches before transplantation. ${ }^{30}$ Alternatively, hydrogels containing MSCs have shown enhanced efficacy compared with direct intramyocardial injection of MSCs. ${ }^{31}$ It remains to be seen whether these benefits will translate into improved outcomes in human clinical studies.

\section{REMAINING QUESTIONS}

In addition to the aforementioned innovative strategies (Figure 1), several basic questions regarding the optimal approach to MSC therapy remain. First, what is the optimal source tissue for human MSCs? Whereas most studies to date have used bone marrow- and adipose tissue-derived MSCs, the umbilical cord and placenta are also excellent sources of human MSCs. ${ }^{5}$ Whether the tissue of origin impacts MSC treatment efficiency remains to be seen. Second, MSCs can be derived in large numbers from autologous or allogeneic sources. ${ }^{5}$ Few studies have compared the relative merits of autologous versus allogeneic MSC therapy. ${ }^{13}$ Furthermore, several studies have demonstrated progressively decreasing number and potency of MSCs with age, suggesting that young individuals may represent optimal cell donors for allogeneic treatment, and calling into question what benefits may be anticipated from autologous therapies with patients with older age without some adjunctive treatment of the cells. ${ }^{5}$ Third, the optimal MSC dose is controversial, with some studies suggesting enhanced benefits with smaller doses ${ }^{13}$ and others requiring higher doses for optimal therapeutic effect. ${ }^{32}$ Moreover, whereas most clinical studies to date have relied on a single injection of MSCs, preclinical evidence suggests that repeated doses are therapeutically superior. ${ }^{33}$ This question is the object of an ongoing clinical trial, the REPEAT (Single Versus Repeated Intracoronary Application of 


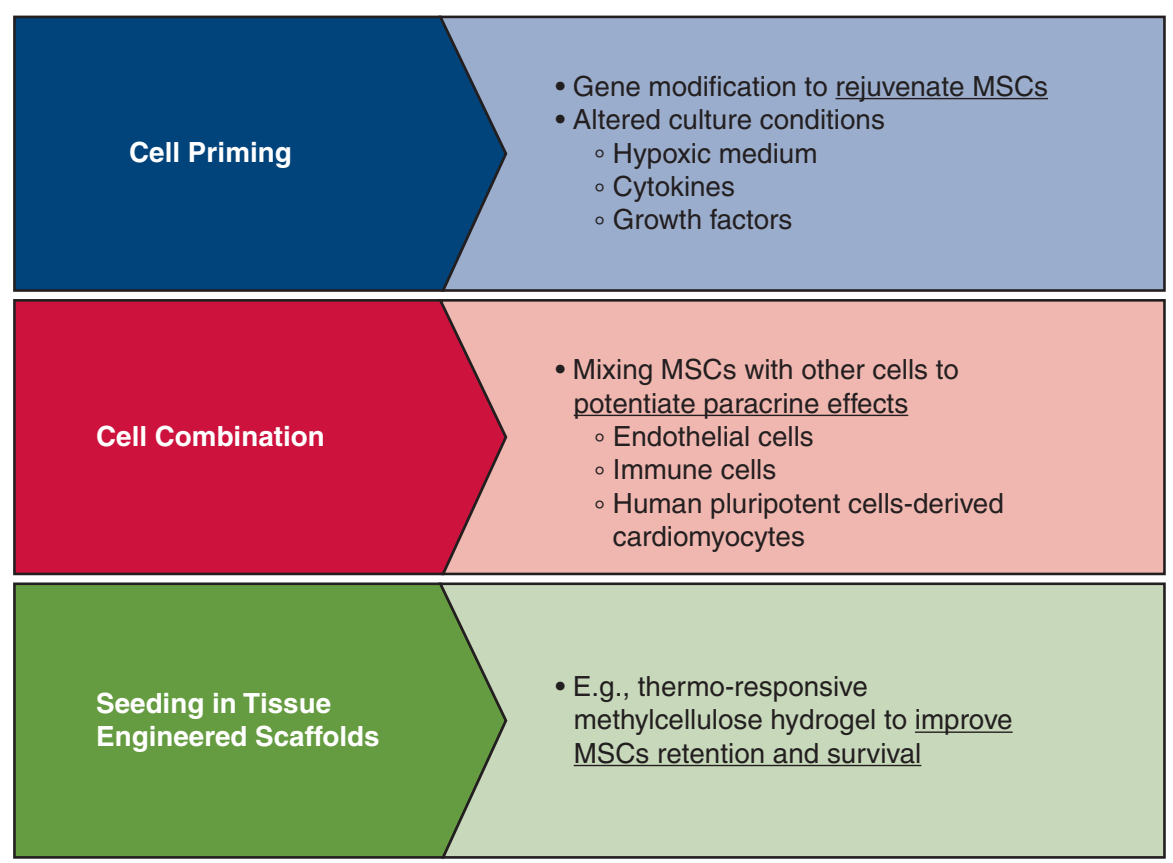

FIGURE 1. Three key potential strategies to improve efficacy of mesenchymal stem cells (MSCs).

Autologous Bone Marrow-derived Mononuclear Cells on Mortality in Patients With Chronic Post-infarction Heart Failure) study (ClinicalTrials.gov Identifier: NCT01693042). Finally, MSCs can be delivered through a number of routes: peripheral venous infusion, transendocardial injection via catheter, direct myocardial injection during open chest surgery, or intracoronary infusion. The lattermost approach may be limited by potential diversion of injected cells from ischemic regions due to coronary obstruction. ${ }^{34}$ The effect of MSCs may be modified by the site of injection (eg, infarcted myocardium, infarct penumbra, or scar tissue). The limited clinical effectiveness of MSC therapy may be due to poor MSC survival related to spontaneous senescence or cell loss induced by local tissue ischemia and other microenvironmental factors. Transplanted MSC survival remains low despite various tissue engineering approaches. Novel ways to overcome the hostile microenvironment may improve MSC survival and effectiveness.

\section{CONCLUSIONS}

The early promise of MSC therapy for ICM remains to some extent unfulfilled. Despite improvements in echocardiogram or MRI parameters in MSC-treated patients, clinical changes noted in Phase 3 trials have largely consisted in QOL benefits and reduced hospitalizations-a limited influence compared with dramatic changes observed in preclinical studies. As a result, MSC therapy has yet to enter the clinical realm in any significant manner, and no regulatory body has endorsed its use in ICM. Despite this, in the United States, an astonishing number of unregulated direct-to-consumer stem cell clinics continue to offer stem cell therapy to patients with heart failure. ${ }^{35}$ Further regulatory efforts are needed to thwart these unauthorized activities which threaten to further damage the public's confidence in the field of stem cell therapy.

Additional work is underway to harness the full potential of MSCs. However, it appears that MSCs cannot contribute new working myocardium to an injured heart. In contrast, other approaches such as transplantation of human pluripotent stem cell-derived cardiomyocytes have shown the ability to remuscularize an infarcted heart in large animal models. ${ }^{36}$ Ultimately, given their advantageous paracrine effects, including desirable proangiogenic properties, one could envision a strategy where MSCs serve as an adjunct to promote the engraftment and survival of human pluripotent stem cell-derived cardiomyocytes. Further research is needed to investigate ways to potentiate MSCs' paracrine effects and evaluate the influence on patient outcomes.

\section{Conflict of Interest Statement}

Dr Yau has consulting relationships with Medtronic, Abbott, and BlueRock Therapeutics. All other authors reported no conflicts of interest.

The Journal policy requires editors and reviewers to disclose conflicts of interest and to decline handling or reviewing manuscripts for which they may have a conflict of interest. The editors and reviewers of this article have no conflicts of interest. 


\section{References}

1. Ambrosy AP, Fonarow GC, Butler J, Chioncel O, Greene SJ, Vaduganathan M, et al. The global health and economic burden of hospitalizations for heart failure: lessons learned from hospitalized heart failure registries. J Am Coll Cardiol. 2014;63:1123-33.

2. Gheorghiade M, Sopko G, De Luca L, Velazquez EJ, Parker JD, Binkley PF, et al. Navigating the crossroads of coronary artery disease and heart failure. Circulation. 2006;114:1202-13.

3. Burnett H, Earley A, Voors AA, Senni M, McMurray JJ, Deschaseaux C, et al. Thirty years of evidence on the efficacy of drug treatments for chronic heart failure with reduced ejection fraction: a network meta-analysis. Circ Heart Fail. 2017; 10:e003529.

4. Dominici M, Le Blanc K, Mueller I, Slaper-Cortenbach I, Marini F, Krause D, et al. Minimal criteria for defining multipotent mesenchymal stromal cells. The International Society for Cellular Therapy position statement. Cytotherapy. 2006;8:315-7.

5. Pittenger MF, Discher DE, Peault BM, Phinney DG, Hare JM, Caplan AI. Mesenchymal stem cell perspective: cell biology to clinical progress. NPJ Regen Med. 2019;4:22.

6. van der Spoel TI, Jansen of Lorkeers SJ, Agostoni P, van Belle E, Gyöngyösi M, Sluijter JP, et al. Human relevance of pre-clinical studies in stem cell therapy: systematic review and meta-analysis of large animal models of ischaemic heart disease. Cardiovasc Res. 2011;91:649-58.

7. Toma C, Pittenger MF, Cahill KS, Byrne BJ, Kessler PD. Human mesenchymal stem cells differentiate to a cardiomyocyte phenotype in the adult murine heart. Circulation. 2002;105:93-8.

8. Grinnemo KH, Mansson-Broberg A, Leblanc K, Månsson-Broberg A, Leblanc K, Corbascio M, et al. Human mesenchymal stem cells do not differentiate into cardiomyocytes in a cardiac ischemic xenomodel. Ann Med. 2006;38: 144-53.

9. Chien KR, Frisen J, Fritsche-Danielson R, Melton DA, Murry CE, Weissman IL. Regenerating the field of cardiovascular cell therapy. Nat Biotechnol. 2019;37: 232-7.

10. Gnecchi M, He H, Liang OD, Melo LG, Morello F, Mu H, et al. Paracrine action accounts for marked protection of ischemic heart by Akt-modified mesenchymal stem cells. Nat Med. 2005;11:367-8.

11. Kinnaird T, Stabile E, Burnett MS, Shou M, Lee CW, Barr S, et al. Local delivery of marrow-derived stromal cells augments collateral perfusion through paracrine mechanisms. Circulation. 2004;109:1543-9.

12. Karantalis V, DiFede DL, Gerstenblith G, Pham S, Symes J, Zambrano JP, et al. Autologous mesenchymal stem cells produce concordant improvements in regional function, tissue perfusion, and fibrotic burden when administered to patients undergoing coronary artery bypass grafting: the Prospective Randomized Study of Mesenchymal Stem Cell Therapy in Patients Undergoing Cardiac Surgery (PROMETHEUS) trial. Circ Res. 2014;114:1302-10.

13. Hare JM, Fishman JE, Gerstenblith G, DiFede Velazquez DL, Zambrano JP, Suncion VY, et al. Comparison of allogeneic vs autologous bone marrowderived mesenchymal stem cells delivered by transendocardial injection in patients with ischemic cardiomyopathy: the POSEIDON randomized trial. JAMA. 2012;308:2369-79.

14. Hare JM, Difede D, Heldman AW. Use of stem cells for ischemic cardiomyopathy-reply. JAMA. 2013;309:1458-9.

15. Heldman AW, DiFede DL, Fishman JE, Zambrano JP, Trachtenberg BH, Karantalis V, et al. Transendocardial mesenchymal stem cells and mononuclear bone marrow cells for ischemic cardiomyopathy: the TAC-HFT randomized trial. JAMA. 2014;311:62-73.

16. Perin EC, Sanz-Ruiz R, Sanchez PL, Lasso J, Pérez-Cano R, Alonso-Farto JC, et al. Adipose-derived regenerative cells in patients with ischemic cardiomyopathy: the PRECISE trial. Am Heart J. 2014;168:88-95.e2.

17. Mathiasen AB, Qayyum AA, Jorgensen E, Helqvist S, Fischer-Nielsen A, Kofoed KF, et al. Bone marrow-derived mesenchymal stromal cell treatment in patients with severe ischaemic heart failure: a randomized placebo-controlled trial (MSC-HF trial). Eur Heart J. 2015;36:1744-53.

18. Mathiasen AB, Qayyum AA, Jørgensen E, Helqvist S, Kofoed KF, HaackSørensen M, et al. Bone marrow-derived mesenchymal stromal cell treatment in patients with ischaemic heart failure: final 4-year follow-up of the MSC-HF trial. Eur J Heart Fail. 2020;22:884-92.

19. Bartolucci J, Verdugo FJ, Gonzalez PL, Larrea RE, Abarzua E, Goset C, et al. Safety and efficacy of the intravenous infusion of umbilical cord mesenchymal stem cells in patients with heart failure: a phase $1 / 2$ randomized controlled trial (RIMECARD trial [randomized clinical trial of intravenous infusion umbilical cord mesenchymal stem cells on cardiopathy]). Circ Res. 2017;121: 1192-204.

20. Yau TM, Pagani FD, Mancini DM, Chang HL, Lala A, Woo YJ, et al. Intramyocardial injection of mesenchymal precursor cells and successful temporary weaning from left ventricular assist device support in patients with advanced heart failure: a randomized clinical trial. JAMA. 2019;321:1176-86.

21. Fisher SA, Doree C, Mathur A, Taggart DP, Martin-Rendon E. Stem cell therapy for chronic ischaemic heart disease and congestive heart failure. Cochrane Database Syst Rev. 2016;12:CD007888.

22. Nowbar AN, Mielewczik M, Karavassilis M, Dehbi HM, Shun-Shin MJ, Jones S et al. Discrepancies in autologous bone marrow stem cell trials and enhancement of ejection fraction (DAMASCENE): weighted regression and meta-analysis. BMJ. 2014;348:g2688.

23. Gonzalez-King H, Garcia NA, Ontoria-Oviedo I, Ciria M, Montero JA, Sepulveda P. Hypoxia inducible factor-1alpha potentiates jagged 1-mediated angiogenesis by mesenchymal stem cell-derived exosomes. Stem Cells. 2017; $35: 1747-59$.

24. Zhou X, Hong Y, Zhang H, Li X. Mesenchymal stem cell senescence and rejuvenation: current status and challenges. Front Cell Dev Biol. 2020;8:364.

25. Qayyum AA, Mathiasen AB, Mygind ND, Kühl JT, Jørgensen E, Helqvist S et al. Adipose-derived stromal cells for treatment of patients with chronic ischemic heart disease (MyStromalCell trial): a randomized placebo-controlled study. Stem Cells Int. 2017;2017:5237063.

26. Bartunek J, Terzic A, Davison BA, Filippatos GS, Radovanovic S, Beleslin B et al. Cardiopoietic cell therapy for advanced ischaemic heart failure: results at 39 weeks of the prospective, randomized, double blind, sham-controlled CHART-1 clinical trial. Eur Heart J. 2017;38:648-60.

27. Bartunek J, Behfar A, Dolatabadi D, Vanderheyden M, Ostojic M, Dens J, et al. Cardiopoietic stem cell therapy in heart failure: the C-CURE (Cardiopoietic stem Cell therapy in heart failURE) multicenter randomized trial with lineagespecified biologics. J Am Coll Cardiol. 2013;61:2329-38.

28. Teerlink JR, Metra M, Filippatos GS, Davison BA, Bartunek J, Terzic A, et al Benefit of cardiopoietic mesenchymal stem cell therapy on left ventricular remodelling: results from the congestive heart failure cardiopoietic regenerative therapy (CHART-1) study. Eur J Heart Fail. 2017;19:1520-9.

29. Patel AN, Henry TD, Quyyumi AA, Schaer GL, Anderson RD, Toma C, et al Ixmyelocel-T for patients with ischaemic heart failure: a prospective randomised double-blind trial. Lancet. 2016;387:2412-21.

30. Huang CC, Tsai HW, Lee WY, Lin WW, Chen DY, Hung YW, et al. A translational approach in using cell sheet fragments of autologous bone marrowderived mesenchymal stem cells for cellular cardiomyoplasty in a porcine model. Biomaterials. 2013;34:4582-91.

31. Ichihara Y, Kaneko M, Yamahara K, Koulouroudias M, Sato N, Uppal R, et al Self-assembling peptide hydrogel enables instant epicardial coating of the heart with mesenchymal stromal cells for the treatment of heart failure. Biomaterials. 2018; 154:12-23.

32. Florea V, Rieger AC, DiFede DL, El-Khorazaty J, Natsumeda M, Banerjee MN, et al. Dose comparison study of allogeneic mesenchymal stem cells in patients with ischemic cardiomyopathy (the TRIDENT study). Circ Res. 2017;121: 1279-90.

33. Guo Y, Wysoczynski M, Nong Y, Tomlin A, Zhu X, Gumpert AM, et al Repeated doses of cardiac mesenchymal cells are therapeutically superior to a single dose in mice with old myocardial infarction. Basic Res Cardiol. 2017; 112:18.

34. Kanelidis AJ, Premer C, Lopez J, Balkan W, Hare JM. Route of delivery modulates the efficacy of mesenchymal stem cell therapy for myocardial infarction: a metaanalysis of preclinical studies and clinical trials. Circ Res. 2017;120:1139-50.

35. Goff ZD, Kichura AB, Chibnall JT, Hauptman PJ. A survey of unregulated directto-consumer treatment centers providing stem cells for patients with heart failure. JAMA Intern Med. 2017;177:1387-8.

36. Liu YW, Chen B, Yang X, Fugate JA, Kalucki FA, Futakuchi-Tsuchida A, et al. Human embryonic stem cell-derived cardiomyocytes restore function in infarcted hearts of non-human primates. Nat Biotechnol. 2018;36:597-605.

Key Words: mesenchymal stem cells, ischemic cardiomyopathy, clinical trials 